ON THE ECONOMIC AND BUDGETARY EFFECTS OF INVESTMENTS IN SCUTS THE PORTUGUESE TOLL-FREE HIGHWAYS *

\author{
Alfredo Marvão Pereira \\ The College of William and Mary and Universidade do Algarve \\ Jorge M. Andraz \\ Universidade do Algarve
}

College of William and Mary

Department of Economics

Working Paper Number 37

Current Version: July 2010

Previous Versions: August 2006

\footnotetext{
* This paper is part of a research project on the "The Economic and Budgetary Impact of Investments in SCUTS" sponsored by the Instituto de Estudos para o Desenvolvimento, Lisbon, Portugal. We would like to thank Rui M. Pereira for very skillful research assistance in this project and an anonymous referee for very useful comments and suggestions. The usual disclaimers apply.
} 
COLLEGE OF WILLIAM AND MARY

DEPARTMENT OF ECONOMICS

WORKING PAPER \# 37

July 2010

\title{
ON THE ECONOMIC AND BUDGETARY EFFECTS OF INVESTMENTS IN SCUTS - THE PORTUGUESE TOLL-FREE HIGHWAYS
}

\begin{abstract}
This paper provides empirical evidence on the economic and budgetary effects of the recent investments in toll-free highways in Portugal, the so-called SCUTS, in an effort to bring some clarity to the current policy debate on these highways. This debate is centered on the issue of the financial sustainability of these highways for the public sector and is derived from the fact that their financing through public-private partnerships and shadow tolls involves regular payments from the public budget to the private firms operating them. In this context, the introduction of tolls has been suggested as a mechanism to alleviate possible budgetary pressures.

Our first main conclusion is that investments in SCUTS have positive economic effects in all regions of the country. Furthermore, we find that regional spillovers account for about threequarters of the total effects of these investments. A paradigmatic case is Lisbon, a region that captures the greatest share of these effects without any investments having actually occurred in the region itself. Our second main conclusion is that investments in SCUTS do not seem to generate problems of financial sustainability for the public budget. We estimate that for all SCUTS, the equilibrium tax rate, i.e., the rate that would balance the tax revenues induced by these highways and the shadow tolls the government has to pay, is lower than the effective tax rate for the economy. As a corollary and from a policy standpoint our results suggest that the introduction of tolls is questionable from a conceptual perspective due to the magnitude of spillovers and seems to be unnecessary from a financial perspective.
\end{abstract}

JEL Codes: C32, H54, and R53

Keywords: public investment, highway investment, regional spillovers.

Alfredo Marvão Pereira

Department of Economics, The College of William and Mary, Williamsburg, USA

CASEE - Center for Advanced Studies in Economics and Econometrics, Universidade do Algarve, Portugal

ampere@,wm.edu

Jorge M. Andraz

Faculdade de Economia, Universidade do Algarve, Campus de Gambelas, 8000 Faro, Portugal CASEE Center for Advanced Studies in Economics and Econometrics, Universidade do Algarve, Faro, Portugal.

jandraz@,ualg.pt 


\section{ON THE ECONOMIC AND BUDGETARY EFFECTS OF INVESTMENTS IN SCUTS - THE PORTUGUESE TOLL-FREE HIGHWAYS}

\section{Introduction}

In the late 1990s, a major expansion of the highway network in Portugal was planned. Under the new National Road Infrastructure Plan, as revised in 1999, the Portuguese highway network was projected to grow by about $60 \%$ by 2007 relative to 1999 . The volume of investment required for this expansion together with a fragile public budgetary situation, led the Portuguese authorities to adopt a regime of financing based on public-private partnerships and shadow tolls. ${ }^{1}$ This financing regime was first introduced in the UK in the early 1990s and is also currently used, albeit to a much lesser degree, in Belgium, Finland, Netherlands, and Spain.

In this regime, private firms are responsible for the design, construction, financing, operation, and maintenance of the highways. As a counterpart, for the period of the concession, typically thirty years, they will receive shadow tolls from the public budget. Therefore, and unlike most of the rest of the highway network in Portugal, the use of these new highways is not subject to the direct payment of tolls by the users. Hence, these highways are referred to as highways in a toll-free regime, or in regime SCUT (Sem Custos para o Utilizador, in Portuguese).

With the adoption of the regime SCUT, the government hoped to reduce the overall cost of these new highways and to accelerate their construction. In fact, under this regime the government managed to smooth its financial commitments over time through the use of shadow tolls -which could be thought of as a substitute for issuing transportation bonds - thereby literally making possible a highway expansion program of this magnitude. In addition, due to the absence of direct tolls, this regime made possible the construction of highways with a high number of access nodes better serving the local populations.

Although the adoption of the regime SCUT seemed to make sense at the time, in the last few years there has been a growing public debate on the desirability of the SCUT highways centered on the issue of their financial sustainability. The problem is that the early estimates of the financial commitments for the public budget have already been substantially revised upward and, therefore, there is a lot of uncertainty over what the actual financial commitments will turn out to be. These additional financial pressures on the public sector are rather unwelcome news in a context of large and persistent public deficits. The fear is that the financing in regime SCUT, as appropriate as it may have originally seemed, may have now become too much of a burden for the public budget.

It is in this context that the idea of introducing tolls on these highways has been considered and has gained greater currency in the recent past with the current recession and its budgetary fallout. At a conceptual level the argument is that these highways serve and benefit mostly the local populations and it is, therefore, appropriate that those who use the infrastructure pay for their use. Ultimately, introducing tolls is thought of as being a way of alleviating the pressure on the public budget caused by the SCUT

\footnotetext{
${ }^{1}$ See, for example, Engle, C., R. Fischer and A. Galetovic (2008, 2009), for an extensive treatment of private-public partnerships.
} 
highways, and more importantly, as an expeditious way of alleviating current budgetary pressures in general. $^{2}$

Despite its intensity, the debate on the SCUTS in Portugal has been seriously handicapped by the absence of any estimates of the potential economic and budgetary effects of these highways. This is a problem that has been identified by, among others, the country's foremost auditing court, in its reports on the SCUT concessions [see Tribunal de Contas $(2003,2005)]$. The intent of this paper is to fill this void by identifying the economic and budgetary effects of the SCUTS as well as their policy implications for the issue of whether or not the introduction of tolls is desirable and/or necessary.

The first objective of this paper is to estimate the economic effects of the investments in SCUTS at both the aggregate and the regional levels. In particular, we want to ascertain whether the benefits generated by each individual SCUT accrue mostly to the region where it is located or instead are spread throughout the country. The evidence on this matter is directly relevant for the conceptual justification of the introduction of tolls in these highways. If each SCUT primarily benefits the region where it is located then the introduction of user fees, i.e. direct tolls, may be conceptually justified. If, however, there are substantial regional spillovers from each SCUT then the conceptual case for tolls is weaker - as under such externalities private pricing may lead to serious underutilization - and financing through the public budget may make sense.

The second objective is to estimate the net economic and budgetary effects of the investments in SCUTS. In this context, we propose a change in the terms of the debate. We set aside the comparison that is central in the current policy debate between the currently expected financial burden and the financial burden initially forecasted. Instead, we start by comparing the projected costs of the SCUTS with their economic impact and then their projected burden for the public budget with their fiscal revenue impact. If the economic benefits are greater than the expected burden, then the investment makes sense from an economic point of view and if the fiscal benefits exceed the financial burden for the public sector, then financial sustainability is not a problem and from this perspective tolls are not necessary.

To identify the effects of the investments in SCUTS we follow a two-step procedure. First, we develop econometric estimates of the marginal effects of road infrastructure investment in Portugal, both at the aggregate level and the regional level. Second, we apply this information to the investments in SCUTS to estimate the effects of these investments, at the regional level, and by SCUT. ${ }^{3}$

Methodologically, this paper follows the approach developed in Pereira (2000, 2001), and Pereira and Andraz (2003) to evaluate the effects of investment in public infrastructures in the United States and adopts a vector-autoregressive (VAR) approach relating output, employment, private investment and investment in road infrastructures. This approach highlights the relevance of dynamic feedbacks. It recognizes that throughout time road infrastructures affect output directly as a factor of

\footnotetext{
${ }^{2}$ It should be noted that although the debate about the desirability of introducing explicit tolls to replace the shadow tolls is not unique to Portugal, the terms of the debate are here substantially different compared to the UK, for example, where the major concerns are congestion and the environmental impacts of these mostly urban highways [see, for example, Bowerman (2007)], concerns hardly applicable to the Portuguese case.

3 Although this is not the first paper to address the issue of infrastructure development in Portugal, it differs from previous contributions at the aggregate level [see, for example, Pereira and Andraz (2005)] and at the regional level [see, for example, Pereira and Andraz (2006)] in that it focuses specifically on road infrastructures and it addresses directly the debate on the highways in regime SCUT.
} 
production as well as indirectly through its effects on the other factors of production. ${ }^{4}$ In addition, this methodology recognizes that over time road infrastructures affect private sector performance but private sector performance also affects road infrastructure investment through its impact on the public budget. Accordingly, it allows for bi-directional causality between road investment and each of the private sector variables as all variables evolve endogenously over time. Furthermore, following Pereira and Andraz (2004, 2006), we estimate separate VAR models for each of the five regions in the country, which road infrastructure investment, both in the region itself and elsewhere in the country. This allows us to identify the regional effects of road infrastructure investments in a framework that makes it possible to identify regional spillovers.

The paper is organized as follows. Section 2 presents the basic data, the econometric framework and the estimation results on the effects of road infrastructure investments in Portugal. Section 3 presents the economic effects of the investments in SCUTS at the regional level and by SCUT. Section 4, discusses the net economic and budgetary effects of the investments in SCUTS. Finally, Section 5 provides a summary and the policy implications of our results.

\section{Data and Preliminary Econometric Results}

\subsection{General data}

We use annual data on output, employment, and investment as well as on road infrastructure investment for the period 1980-98. The choice of the sample period is determined by the availability of data on road infrastructure investment but it also suits perfectly the purpose of this paper - to analyze the effects of road investments undertaken beginning in 1999. Our results, therefore, reflect the economic conditions and the relative scarcity of road infrastructures at the time.

We consider aggregate data and regional data for the five administrative regions in the country North, Center, Lisbon, Alentejo, and Algarve. If we think about the country as a rectangle, the long sides being the western Atlantic Ocean front and the eastern Spanish border, these five regions are five contiguous segments from the north to the south of the country.

Data on output and employment comes from annual issues of the Regional Accounts published by the National Institute of Statistics, which for the period after 1990 are available at http://www.ine.pt. Regional private investment data, which is not available from official sources, was constructed as aggregate investment weighted by the region's output share. In turn, data for investments in road infrastructures comes from Pereira and Andraz (2001). It includes investments in national roads, municipal roads and highways. The evolution of road investment in Portugal has been closely related to the EU structural transfer programs in the form of Community Support Frameworks (CSFs). The sample period includes ten years covered by the first and the second programs, 1989-99. The possibility of structural breaks due to the two programs is fully incorporated into the econometric analysis.

\footnotetext{
${ }^{4}$ It is also consistent with the often stated policy objectives of promoting growth through infrastructure development while creating private sector jobs and creating a favourable atmosphere for private investment.
} 


\subsection{Unit-roots, co-integration, and model specification ${ }^{5}$}

To investigate the order of integration of the different variables, we used the ADF t-test and the BIC criterion to determine the optimal number of lagged differences in the regressions. Deterministic components and dummies for the periods of the two CSFs were included if statistically significant. We started by applying the ADF t-tests to regional output, employment, private investment and road infrastructure investment, in log-levels and consistently found non-stationarity. We then tested for stationarity in growth rates. The ADF t-tests results suggested that the null hypothesis of a unit root in the growth rates could be rejected for virtually all of the regional level variables. We took this as a strong indication that stationarity in growth rates is a good approximation for all variables.

Then we tested for co-integration at both the aggregate and regional levels, among output, employment, private investment and road infrastructure investment. Due to our relatively small sample we used the Engle-Granger procedure, which is less vulnerable than the Johansen procedure to the small sample bias toward finding co-integration when it does not exist [Gonzalo and Lee (1998) and Gonzalo and Pitarakis (1999)]. Following the standard Engle-Granger approach, we performed four tests in each case. This is because it is possible that one of the variables enters the co-integrating relationship with a statistically insignificant coefficient and a test that uses such a variable as the endogenous variable will not pick up the co-integration. Therefore, a different variable is endogenous in each of the four tests. We applied the ADF t-test to the residuals from the regressions of each variable on the remaining variables. The optimal lag structure was chosen using the BIC, and a deterministic component and dummies for the periods of the two CSF programs were included if statistically significant. The values of the t-statistics were consistently larger than the $5 \%$ critical values. Thus, we could not reject the null hypothesis of no co-integration for any region.

Having determined that all the variables are stationary in first differences of log levels and that they are not co-integrated, we followed the standard procedure in the literature and proceed to estimate VAR models in growth rates. We estimated region-specific VAR models including, in addition to the region-specific variables, road infrastructure investment in the rest of the country. These models, therefore, take into account the existence for each region of spillover effects produced by the road infrastructure investment in other regions.

The VAR specification has three jointly determined dimensions - the determination of the lag order, the specification of the deterministic components, and the possibility of structural breaks. In order to consider possible structural changes due to the two CSFs, we distinguished three periods - the period before 1989, the period of first CSF program (1989-93), and the period of the second CSF program (1994-98). Therefore, we considered three alternatives in terms of the VAR specification - no structural break/no dummies, one structural break/one dummy distinguishing the periods before and after 1989, and two structural breaks/two dummies reflecting the possibility of the three different periods mentioned above. We found that for all the models the BIC criterion led to the selection of VAR specifications of first order with a deterministic constant and a trend and with two structural breaks.

\footnotetext{
${ }^{5}$ For the sake of brevity, details of these preliminary tests and of the basic estimation results are not presented in the paper but are readily available from the authors upon request.
} 


\subsection{Identifying and measuring the effects of innovations in road infrastructure investment}

We used the impulse-response functions associated with the estimated VAR models to obtain the effects of one-time shocks in the rate of growth of road infrastructure investments. The central issue for the determination of these effects is the identification of shocks that are not contemporaneously correlated with shocks in the other variables, that is, innovations in road infrastructure investment that are not subject to the problem of reverse causality. In dealing with this issue we drew from the approach typically followed in the literature on the effects of monetary policy [see, for example, Christiano, Eichenbaum and Evans (1996, 1998), and Rudebusch (1998)], and estimate policy functions for road infrastructure investment. The residuals of this function represent the non-systematic component of road infrastructure investment which, by definition are not contemporaneously correlated with innovations in the remaining variables. This approach was adapted to the analysis of the effects of public capital formation in Pereira $(2000,2001)$ and the details about its application at the regional level may be found in Pereira and Andraz (2004, 2006).

We report the long-term marginal products which measure the long-term accumulated effects in the other variable of one million euros accumulated change in road infrastructure investment either in the region itself or elsewhere in the country. Long term is defined as the time horizon over which the growth effects of innovations disappear. We obtain the marginal product figures by multiplying the long-term elasticities obtained from the impulse response functions by the average ratio for the last ten years of the sample of the corresponding variable to road infrastructure investment. This allows us to interpret the marginal products as the long-term effects of road investments that take place under the conditions observed by the end of the sample period while at the same time avoiding business cycle effects.

\subsection{On the effects of investment in road infrastructure}

Our methodology allows us to identify for each region, both the effects of a one million euro investment in road infrastructures in the regions itself and the effects of a one million euro investment in elsewhere in the country, the spillover effects. The estimation results are reported in Table 1.

We start by considering the effects on regional private investment. The region that benefits the most from local investment in road infrastructure is Lisbon, followed by Algarve and North. These effects are marginally positive for Center and marginally negative for Alentejo. As to the effects for a region of road investment elsewhere, the greatest beneficiary is Lisbon. The benefits are substantially lower for

Center and North and much more so for Alentejo and Algarve. In terms of employment, the region that benefits the most from local road investment is Center, followed by Algarve and Lisbon. In turn, road investments in the North and in Alentejo actually induce a reduction in local employment. At the same time, the spillover effects are positive for all regions with the largest effects in Lisbon, North and Center. Finally, in terms of output, the largest effects from local road investment occur in Algarve followed by Lisbon, Center and North. The effects for Alentejo are negative. In turn, the spillover effects while positive for all regions are by far the largest for Lisbon. 


\section{On the Economic Effects of Investments in SCUTS}

\subsection{Investments in SCUTS}

There are seven highways operated in the regime SCUT: SCUT of Beira Interior, SCUT of Beiras Litoral e Alta, SCUT of Grande Porto, SCUT of Litoral Norte, SCUT of Costa de Prata, SCUT of Algarve, and SCUT of Interior Norte. Construction started in 1999 and was concluded in 2007. The information about investments in SCUTS was provided directly by the different private operators and is presented in Table 2. Investment in construction is estimated to total 2.7 billion euros in 1999 prices, which corresponds to $2.6 \%$ of the 1999 GDP. The regional distribution of construction investments is reported in Table 3. Lisbon is the only region in which no SCUT is located while investments in Alentejo are rather marginal. North accounts for $50.8 \%$ of the investments while Center represents $41.3 \%$.

With this information, we are now in a position to identify the economic impact of the investments in the SCUT highways. The starting point is the information about the investments for the seven SCUTS, as presented in Table 2, and their regional distribution as reported in Table 3. Then, based on the estimates of the direct and spillover regional effects of road infrastructure investments, as presented in Table 1, we are able to identify the regional direct and spillover effects of the investments in SCUTS, as well as the regional effects of each individual SCUT.

\subsection{On the regional economic effects of investments in SCUTS}

The regional effects of investments in SCUTS are reported in Table 4. All regions benefit from these investments albeit to different degrees depending on the variable under consideration. Accordingly, the aggregate benefits - the sum of the regional effects - are consistently positive. We find that investments in SCUTS induce, in the long term, an accumulated increase of 23.0 billion euros in private investment, the creation of approximately 66.7 thousand new jobs, and an increase of output of 49.2 billion euros. As a term of comparison, these effects represent $72.0 \%$ of the private investment, $1.3 \%$ of the work force, and $41.7 \%$ of GDP in 1999, respectively.

In terms of private investment, the greatest beneficiary is Lisbon, a region that captures $41.8 \%$ of the total effects. North captures $27.5 \%$, Center $16.8 \%$, Alentejo $8.2 \%$ and, finally, Algarve 5.7\%. Our results highlight the critical importance of the spillover effects. On the aggregate, the spillovers represent $77.2 \%$ of the total effects and constitute the most important effect for Center, Lisbon and Alentejo. Even in the other regions, the spillover effects are significant. They represent $30.2 \%$ and $42.2 \%$ of the total effect for North and Algarve, respectively. Finally, the benefits captured by each region are in line with the region's share of private investment and, therefore, investments in SCUTS do not seem to affect substantially the regional allocation of private investment.

In terms of employment, the largest beneficiaries are Center and Lisbon with $41.8 \%$ and $36.5 \%$ of the benefits, respectively. Algarve captures 11.6\%, North 5.3\%, and Alentejo $4.8 \%$. Here, again, the spillover effects are very important, representing $70.2 \%$ of the total effects, and exceeding the direct effects in all regions except for Center. As to the gains relative to the region's shares of employment, the results suggest that investments in SCUTS will lead to important changes in the regional composition of employment. The big winners in relative terms are Center and Algarve. Together they capture $53.4 \%$ of 
the benefits and accounts for only $21.7 \%$ of employment. Lisbon and Alentejo capture benefits that are in line with their shares of employment while the big loser is North, which captures $5.3 \%$ of the total benefits but $26.6 \%$ of employment.

In terms of output, the greatest beneficiary is again Lisbon with $47.8 \%$ of the total gains. In turn, Center, Alentejo, Algarve, and North capture 23.5\%, 13.5\%, 9.6\% and 5.6\% of total effects, respectively. In line with our results for both private investment and employment, the spillover effects are very important representing $78.5 \%$ of the total effect and are more important than the direct effects in all regions except for Center. Finally, the benefits captured by the different regions are in line with their output shares, with the exception of North, which has a share of $31.5 \%$ of output and captures only $5.6 \%$ of the effects of investment. This result suggests important movements in the regional composition of output away from the North.

One fact that is apparent from Table 4 is the great relevance of the spillover effects, reflecting a high degree of integration of the economic fabric of what is a relatively small country. More specifically, the only region for which the direct output effects are more important than the spillover effects is Center while for Lisbon and Alentejo all positive output effects are actually spillover effects. The case of Lisbon is paradigmatic in that no investment in SCUTS actually occurs in the region itself. Because of its economic importance in absolute terms and its central role in the economic fabric of the country Lisbon is nevertheless able to capture a large share of the benefits of the investments in SCUTS.

\subsection{On the economic effects by SCUT}

The effects on private investment are reported in the top panel of Table 5. The largest effects are generated by investments in the SCUT of Interior Norte and the SCUT of Grande Porto, with 21.7\% and $20.7 \%$ of total effects, respectively, followed by the SCUTS of Beiras Litoral e Alta and Beira Interior with $14.0 \%$ and $13.4 \%$, respectively. Finally, the SCUT of Litoral Norte accounts for $12.0 \%$, the SCUT of Algarve for $10.2 \%$ and the SCUT of Costa de Prata for $8.0 \%$. In relative terms, the SCUTS of Grande Porto, Litoral Norte, Algarve and Interior Norte generate benefits that are disproportionately larger than their share of the overall investment in SCUTS. They represent $50.6 \%$ of the investments and generate $64.6 \%$ of the benefits.

The results for employment are reported in the middle panel of Table 5. The largest effects are generated by the investments in the SCUTS of Beiras Litoral e Alta and Beira Interior, with $28.7 \%$ and $26.7 \%$ of total effects. These are followed by the effects from the SCUTS of Interior Norte with $13.3 \%$, Costa de Prata with 10.2\%, Algarve with 9.6\%, Grande Porto with 7.3\%, and Litoral Norte with 4.2\%. In relative terms, the effects on employment of investment in the SCUTS of Costa de Prata and Algarve are in line with their shares of total investment in SCUTS. However, the effects from the SCUTS of Beira Interior and Beiras Litoral e Alta are clearly above their shares of investment. Together they generate $55.4 \%$ of total benefits but represent just $40.3 \%$ of total investment. In turn, the SCUTS of Grande Porto, Litoral Norte and Interior Norte generate benefits that are disproportionately lower than their shares of investment. Their benefits are $24.8 \%$ of the total while they represent $43.5 \%$ of total investment.

Finally, the results on output are reported in bottom panel of Table 5. The largest effects are generated by investments in the SCUTS of Beiras Litoral e Alta and of Beira Interior, with $22.4 \%$ and 
$20.9 \%$ of total effects, respectively. The effects from investment in the SCUT of Interior Norte represent $16.9 \%$ of the total effects, followed by the effects from investments in the SCUTS of Grande Porto, with 13.1\%, of Algarve, with 9.8\%, of Costa de Prata, with 9.3\% and of Litoral Norte with 7.6\%. The effects on output tend to follow the share of each SCUT in total investment, with the SCUTS of Beira Interior and of Beiras Litoral e Alta inducing benefits slightly higher than their share of investment.

\section{On the Net Economic and Budgetary Effects of Investments in SCUTS}

Based on the estimates presented in the previous section we are now in a position to address the issues of the net economic and budgetary impacts of the investments in SCUTS. If the economic benefits of the SCUTS are greater than the expected financial burden they induce on the private sector and the public budget, then these investments made sense from an economic point of view. Moreover, if the fiscal benefits induced by these investments exceed the expected financial burden for the public budget, then financial sustainability is not a problem.

\subsection{The basic data on costs for the private operators and the public sector}

We start by considering the investment costs for the private operators of the SCUTS. Naturally, aside from construction costs presented in Tables 2 and 3, operating the SCUTS involves management, maintenance, repairs, and improvement costs. When these additional costs are considered investments in SCUTS reach - according to the different SCUT private operators - 4.4 billion euros or $3.6 \%$ of the 1999 GDP. The present discounted values of these private costs for each SCUT, at a discount rate of $3 \%$, are presented in the first column of Table 6.

In addition, since the counterpart to the private concessions is the payment of shadow tolls and other contractual obligations by the government, the SCUTS represent a financial burden for the public budget. The financial burden corresponding to the shadow tolls was originally estimated by the Tribunal de Contas [2003] and was more recently updated to reach 10.5 billion euros or $10.2 \%$ of the 1999 GDP. The consideration of other financial responsibilities, such as expropriations, increases the total burden to 11.3 billion of euros or $11.0 \%$ of the 1999 GDP. The present discounted values of these costs for the public sector for each SCUT, at a discount rate of 3\%, are presented in the second column of Table 6 as well as the first column of Table 7.

\subsection{On the net economic impact of the SCUTS}

We start by comparing the estimated benefits of the SCUTS in the form of increased output over time (last column of Table 6) with the total costs of the SCUTS, including both total investments incurred by the private concessionary firms (first column of Table 6) and the expected financial burden for the public sector (second column of Table 6).

Our results suggest that both at the aggregate level and for each of the SCUTS, the estimated benefits exceed the total costs and, therefore, the investments in SCUTS are clearly justified from an economic perspective. At the aggregate level total investments in SCUTS induce costs over time, which 
represent $10.5 \%$ of the 1999 GDP while the effects on output over time represent $41.5 \%$. This implies a benefit-cost ratio of 3.95. The same pattern is true at the level of each individual SCUT in that in all cases the positive effect on output exceeds the total costs involved. In some cases such as the SCUTS of Beira Interior, Beiras Litoral e Alta, Algarve, and Interior Norte, the differences are quite large, with implicit benefit-cost ratios well in excess of 4.0. As a corollary from a policy perspective it can be said that the investment in SCUTS was a good idea for the country at the time.

\subsection{On the net budgetary impact of the SCUTS}

We now compare the financial burden the SCUTS place on the public budget (first column of Table 7) with the additional future tax revenues that will be generated by the SCUTS (second column of Table 7). Since the SCUTS are estimated to lead to an increase in output over time, they will also lead to an increase in the tax base over time. We estimate the additional tax revenues generated by the SCUTS using a tax rate of $21.0 \%$, the effective tax rate for the economy over the last decade. We also report (third column of Table 7) the equilibrium tax rate, i.e., the tax rate that given the estimated effects on output would equate the fiscal revenues induced by the SCUTS to the expected financial burden.

At the aggregate level, our results suggest that the financial burden to the public budget induced by the SCUTS is below the estimated fiscal revenues generated by the SCUTS. Indeed, the additional tax revenues represent $8.7 \%$ of the 1999 GDP and the financial burden represents $7.0 \%$. The equilibrium tax rate is $16.8 \%$, clearly below the effective tax rate of $21.0 \%$. When we consider the situation for each individual SCUT a richer picture emerges. For the SCUTS of Interior Norte, Beira Interior, Beira Litoral e Norte, and Algarve, the equilibrium tax rates are 17.3\%, 14.8\%, 15.8\% and $12.4 \%$, respectively, and therefore are comfortably below the effective tax rate for the economy. In turn, for the SCUTS of Litoral Norte and of Costa da Prata, and Grande Porto the equilibrium tax rates are 20.9\% and 20.8\%, and $19.5 \%$ which are very close to the effective tax rate for the economy.

Overall one could say that while the investments in SCUTS taken as a whole does not represent a net burden for the public sector there are areas of vulnerability. These are the SCUTS of Litoral Norte and of Costa da Prata, and Grande Porto for which any further slippage from the currently projected financial burdens for the public sector may indeed cause a net burden on the public budget over time.

\section{Summary and Policy Implications}

This paper is motivated by the absence of estimates for the economic and budgetary effects of the investments in SCUTS necessary to substantiate the current public debate on their financial sustainability. With this in mind we set out to accomplish two objectives: first, to identify the economic effects of the SCUTS and, in particular, the relevance of the regional spillover effects; second, to address the issue of the budgetary sustainability of the SCUTS.

In terms of the first objective, we find that all regions benefit from the investments in SCUTS albeit to a different degree - Lisbon and Center capture the bulk of the benefits. Furthermore, when we consider for each individual SCUT the relationship between its economic benefits - in the form of added 
output, and its costs - both for the private operators and the public sector, we find benefit-cost ratios on average around four and in several cases substantially larger. As a corollary from a policy perspective it can be said that the investment in SCUTS was a good idea for the country at the time. This naturally does not mean that it was the best investment strategy at the time or that this is a strategy that should be followed again now.

In a related vein, our estimates of the economic effects of the investments in SCUTS establish the critical importance of regional spillovers. A paradigmatic case is Lisbon, which captures the lion's share of the effects of the investments in SCUT despite the fact that no investment in SCUTS actually took place in the region itself. This evidence implies that the conceptual argument for the introduction of tolls - those who use the freeways should pay for their use - is weak. Since the bulk of the benefits of each SCUT are disseminated throughout the country, financing from the public budget makes sense. In fact, the introduction of tolls in the presence of large spillover effects could lead to serious underutilization of the freeways - an efficiency argument. It could also mean that the residents of less affluent regions where the SCUT are located would end up effectively financing the development of more affluent regions, Lisbon being a glaring case - an equity argument.

In terms of the second objective, our main conclusion is that investments in SCUTS do not seem to generate problems of financial sustainability for the public sector. We show that the potential tax revenues induced by the SCUTS are larger than with the financial burden implied by the payment of virtual tolls and other contractual obligations for each and every SCUT. This suggests that all SCUTS pay for themselves in the form of increased future tax revenues and that, therefore, the, introduction of tolls is not necessary from a budgetary perspective.

The cases of the three of the SCUTS, Grande Porto, Litoral Norte, and Costa de Prata, however, are worth mentioning in this context since they are the most vulnerable cases from a financial perspective and the ones that seem to lend themselves more than any other to the possibility of introduction of tolls. ${ }^{6}$ It should be pointed out, however, that while our results open the door to the possibility of introducing tolls in these freeways for financial reasons they do not establish this as the right course of action. Indeed, aside from the considerations of efficiency and equity mentioned above, there are a variety of complicating factors when it comes to the financial sustainability argument for introducing tolls.

First and foremost there is the potential economic impact of introducing tolls. The introduction of tolls will necessarily reduce the use of the freeways in favor of alternative routes and thereby decrease their economic and fiscal benefits. How much of the current traffic would be diverted by the introduction of the tolls is to be determined. ${ }^{7}$ What would be the net benefit for the public budget - reduced burden of the virtual tolls together with lower future tax revenues induced by economic impact of the use of the freeways - is also to be determined. How much the private operators would need to be compensated for the contractual changes implied by the introduction of tolls is again to be determined.

\footnotetext{
${ }^{6}$ Consistently, but not coincidentally, these are the three SCUTS the Portuguese government has recently chosen to introduce tolls effective August 1, 2010 conditional on a variety of political and contractual arrangements.

${ }^{7}$ The Portuguese stock market seems to reflect the belief that the introduction of tolls will greatly reduce the use of SCUTS in favor of alternative routes by translating the announcement of the introduction of tolls into clear stock market gains for the companies operating the current toll-based freeways.
} 
Additionally, there is a question of practicality. The implementation of actual tolls in freeways which were designed to have a very large number of access is a rather complicated matter. Introducing physical toll collection areas is very costly - estimated to be equivalent to about three years of shadow tolls - and time consuming - estimated to take at least three years to develop - and would inevitably eliminate a large number of local access nodes. In turn, the introduction of mandatory and comprehensive electronic toll mechanisms is liable to be complicated by legal issues of privacy and constitutionality. In either case, the myriad of exemptions being considered for local residents and businesses in many of the localities served by the SCUTS can only make matters more complicated.

From a strategic point of view, our results establish that overall the investments in SCUTS make sense from an economic perspective, do not generate serious budgetary problems, and that the introduction of tolls is neither conceptually justified nor financially necessary. They also suggest that the debate in Portugal about the sustainability of the SCUTS and the desirability of introducing tolls may be excessively contaminated by the current budgetary concerns. ${ }^{8}$ Indeed, the introduction of tolls is widely regarded as a revenue raising strategy more palatable than increasing taxes. The argument that introducing tolls on the SCUTS is important from a budgetary perspective, merely as a revenue raising strategy, can certainly be entertained. Its merits, however, should be considered vis-à-vis other budgetary control measures. Furthermore, regardless of its motivation, the introduction of tolls could, according to the evidence presented in this paper, have serious negative economic, efficiency and equity effects.

\footnotetext{
${ }^{8}$ It is only under the current extreme budgetary pressures that the introduction of tolls finally got some political momentum and indeed the debate has moved from introducing tolls in the three vulnerable SCUTS to introducing tolls in all seven SCUTS regardless of financial sustainability concerns.
} 


\section{References}

Bowerman, A. (2007): "The Costs and Benefits of Road Pricing," Institute of Economic Affairs, Working Paper No. 18.

Christiano, L., M. Eichenbaum and C. Evans (1996): "The Effects of Monetary Policy Shocks: Evidence from the Flow of Funds," Review of Economics and Statistics 78(1), pp. 16-34.

Christiano, L., M. Eichenbaum and C. Evans (1998): "Monetary Policy Shocks: What Have We Learned and to What End?" NBER Working Paper 6400.

Engle, C., R. Fischer and A. Galetovic (2008): “The Basic Public Finance of Public-Private Partnerships,” NBER Working Paper No. 13284.

Engle, C., R. Fischer and A. Galetovic (2009): "Public-Private Partnerships: When and How," mimeo Yale University.

Gonzalo, J. and T. Lee (1998): "Pitfalls in Testing for Long-Run Relationships," Journal of Econometrics 86, pp. 129-154.

Gonzalo, J. and J. Pitarakis (1999): "Dimensionality Effect in Cointegration Analysis," in Festschrift in Honor of Clive Granger, R. Engle and H. White Eds., Oxford University Press, 212-29.

Pereira, A. M. (2000): “Is All Public Capital Created Equal?" Review of Economics and Statistics, 82(3), 513-18.

Pereira, A. M. (2001): "Public Capital Formation and Private Investment: What Crowds in What?" Public Finance Review, 29(1), 3-25.

Pereira, A. M. e J. M. Andraz (2001): Investimento Público em Infra-estruturas de Transporte em Portugal Continental, Secretaria de Estado do Planeamento/Ministério do Planeamento.

Pereira, A. M. e J. M. Andraz (2003): "Public Capital and Growth in the US: a Sector-specific Analysis," Public Finance Review 31(1), 66-90.

Pereira, A. M. e J. M. Andraz (2004): "Public Highway Spending and State Spillovers in the US," Applied Economics Letters 11, 785-8.

Pereira, A. M. e J. M. Andraz (2005): "Public Investment in Transportation Infrastructures and Economic Performance in Portugal," Review of Development Economics 9, 177-196.

Pereira, A. M. e J. M. Andraz (2006): "Public Investment in Transportation Infrastructures and Regional Asymmetries in Portugal," Annals of Regional Science 40, 803-817.

Rudebusch, G. D. (1998): "Do Measures of Monetary Policy in a VAR Make Sense?" International Economic Review, 39(4), pp. 907-931.

Tribunal de Contas (2003) Auditoria às Concessões Rodoviárias em Regime de Portagem Scut, Relatório de Auditoria no 14/2003 - 2ª Secção.

Tribunal de Contas (2005) Auditoria às Concessões Rodoviárias em Regime de Portagem Scut - follow

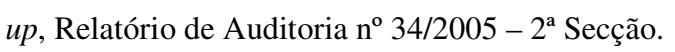


Table 1: Regional effects of road infrastructure investment in Portugal

\begin{tabular}{|c|c|c|c|c|c|c|}
\hline \multirow{3}{*}{ Regions } & \multicolumn{2}{|c|}{$\begin{array}{l}\text { Private investment } \\
\end{array}$} & \multicolumn{2}{|c|}{ Employment } & \multicolumn{2}{|c|}{ Output } \\
\hline & \multicolumn{2}{|c|}{$\begin{array}{l}\text { Marginal products relative to } \\
\text { investment located }\end{array}$} & \multicolumn{2}{|c|}{$\begin{array}{l}\text { Marginal products relative to } \\
\text { investment located }^{* * *}\end{array}$} & \multicolumn{2}{|c|}{$\begin{array}{c}\text { Marginal products relative to } \\
\text { investment located }\end{array}$} \\
\hline & $\begin{array}{l}\text { In the } \\
\text { region }\end{array}$ & $\begin{array}{c}\text { Elsewhere in the } \\
\text { country }\end{array}$ & $\begin{array}{l}\text { In the } \\
\text { region }\end{array}$ & $\begin{array}{c}\text { Elsewhere in the } \\
\text { country }\end{array}$ & In the region & $\begin{array}{c}\text { Elsewhere in the } \\
\text { country }\end{array}$ \\
\hline North & 3.91 & 1.19 & -4.70 & 5.53 & 0.42 & 1.43 \\
\hline Center & 0.06 & 2.82 & 16.30 & 3.96 & 5.93 & 2.49 \\
\hline Lisbon & 5.58 & 7.54 & 11.20 & 15.10 & 7.33 & 11.99 \\
\hline Alentejo & -0.06 & 0.70 & -1.10 & 1.15 & -1.74 & 2.47 \\
\hline Algarve & 3.95 & 0.22 & 13.70 & 2.03 & 10.04 & 1.11 \\
\hline
\end{tabular}

Table 2: Investment in the construction of SCUTS by year

\begin{tabular}{|c|c|c|c|c|c|c|c|c|}
\hline Years & $\begin{array}{c}\text { SCUT } \\
\text { Beira } \\
\text { Interior }\end{array}$ & $\begin{array}{c}\text { SCUT } \\
\text { Beiras } \\
\text { Litoral e } \\
\text { Alta }\end{array}$ & $\begin{array}{c}\text { SCUT } \\
\text { Grande } \\
\text { Porto }\end{array}$ & $\begin{array}{c}\text { SCUT } \\
\text { Litoral } \\
\text { Norte }\end{array}$ & $\begin{array}{c}\text { SCUT } \\
\text { Costa de } \\
\text { Prata }\end{array}$ & $\begin{array}{c}\text { SCUT } \\
\text { Algarve }\end{array}$ & $\begin{array}{c}\text { SCUT } \\
\text { Interior } \\
\text { Norte }\end{array}$ & $\begin{array}{c}\text { Total } \\
\text { Investment }\end{array}$ \\
\hline 1999 & 23.039 & 0 & 0 & 0 & 0 & 0 & 0 & 23.039 \\
\hline 2000 & 55.375 & 0 & 0 & 0 & 0 & 2.130 & 1.167 & 58.673 \\
\hline 2001 & 189.437 & 1.340 & 0 & 1.848 & 5.668 & 41.613 & 26.993 & 266.898 \\
\hline 2002 & 207.100 & 27.906 & 3.052 & 1.391 & 22.972 & 103.285 & 42.410 & 408.117 \\
\hline 2003 & 56.488 & 100.864 & 17.916 & 31.287 & 80.664 & 46.135 & 66.706 & 400.060 \\
\hline 2004 & 2.795 & 170.150 & 67.404 & 116.351 & 100.726 & 0 & 88.424 & 545.851 \\
\hline 2005 & 0 & 211.789 & 216.624 & 78.979 & 385 & 0 & 99.296 & 607.072 \\
\hline 2006 & 0 & 52.104 & 119.882 & 16.932 & 27.992 & 0 & 171.121 & 388.031 \\
\hline 2007 & 0 & 0 & 0 & 0 & 11.134 & 0 & 16.437 & 27.572 \\
\hline Total & 534.235 & 564.154 & 424.877 & 246.787 & 249.542 & 193.163 & 512.556 & $2,725.314$ \\
\hline$\%$ of 1999 PIB & $\mathbf{0 , 5 2}$ & $\mathbf{0 , 5 5}$ & 0,41 & 0,24 & 0,24 & 0,19 & $\mathbf{0 , 5 0}$ & 2,64 \\
\hline
\end{tabular}

Table 3: Investment in the construction of SCUTS by region

\begin{tabular}{|c|c|c|c|c|c|c|c|c|}
\hline Regions & $\begin{array}{c}\text { SCUT } \\
\text { Beira } \\
\text { Interior }\end{array}$ & $\begin{array}{c}\text { SCUT } \\
\text { Beiras } \\
\text { Litoral e } \\
\text { Alta } \\
\end{array}$ & $\begin{array}{c}\text { SCUT } \\
\text { Grande } \\
\text { Porto }\end{array}$ & $\begin{array}{c}\text { SCUT } \\
\text { Litoral } \\
\text { Norte }\end{array}$ & $\begin{array}{c}\text { SCUT } \\
\text { Costa de } \\
\text { Prata }\end{array}$ & $\begin{array}{c}\text { SCUT } \\
\text { Algarve }\end{array}$ & $\begin{array}{c}\text { SCUT } \\
\text { Interior } \\
\text { Norte }\end{array}$ & Total Investment \\
\hline North & & & 424.877 & 246.787 & 74.863 & & 379.291 & $\begin{array}{l}1,125.818 \\
(41.3 \%)\end{array}$ \\
\hline Center & 512.866 & 564.154 & & & 174.679 & & 133.265 & $\begin{array}{l}1,384.964 \\
(50,8 \%)\end{array}$ \\
\hline \multicolumn{9}{|l|}{ Lisbon } \\
\hline Alentejo & 21.369 & & & & & & & $\begin{array}{l}21.369 \\
(0.8 \%)\end{array}$ \\
\hline Algarve & & & & & & 193.163 & & $\begin{array}{l}193.163 \\
(7,1 \%)\end{array}$ \\
\hline Total & $\begin{array}{c}534.235 \\
19.6 \%\end{array}$ & $\begin{array}{c}564.154 \\
20.7 \%\end{array}$ & $\begin{array}{l}424.877 \\
15.6 \%\end{array}$ & $\begin{array}{c}246.787 \\
9.1 \%\end{array}$ & $\begin{array}{c}249.542 \\
9.2 \%\end{array}$ & $\begin{array}{c}193.163 \\
7.1 \%\end{array}$ & $\begin{array}{c}512.556 \\
18.8 \%\end{array}$ & $\begin{array}{l}2,725.314 \\
100.0 \%\end{array}$ \\
\hline
\end{tabular}

Unit: million 1999 euros 
Table 4: On the regional effects of investment in SCUTS

\begin{tabular}{|c|c|c|c|c|c|c|c|c|c|}
\hline \multirow[b]{3}{*}{ Regions } & \multicolumn{3}{|c|}{ Effects on Private investment* } & \multicolumn{3}{|c|}{ Effects on Employment** } & \multicolumn{3}{|c|}{ Effects on Output* } \\
\hline & \multicolumn{2}{|c|}{ Investment located } & \multirow[b]{2}{*}{$\begin{array}{c}\text { Total } \\
\text { effects }\end{array}$} & \multicolumn{2}{|c|}{ Investment located } & \multirow[b]{2}{*}{$\begin{array}{c}\text { Total } \\
\text { effects }\end{array}$} & \multicolumn{2}{|c|}{ Investment located } & \multirow[b]{2}{*}{$\begin{array}{l}\text { Total } \\
\text { effects }\end{array}$} \\
\hline & $\begin{array}{l}\text { In the } \\
\text { region }\end{array}$ & $\begin{array}{l}\text { Elsewhere in } \\
\text { the country }\end{array}$ & & $\begin{array}{l}\text { In the } \\
\text { region }\end{array}$ & $\begin{array}{l}\text { Elsewhere in } \\
\text { the country }\end{array}$ & & $\begin{array}{l}\text { In the } \\
\text { region }\end{array}$ & $\begin{array}{l}\text { Elsewhere } \\
\text { in the } \\
\text { country }\end{array}$ & \\
\hline North & 4.403 & 1.903 & $\begin{array}{r}6.306 \\
27.5 \%\end{array}$ & -5.292 & 8.795 & $\begin{array}{l}3.503 \\
5.3 \%\end{array}$ & 468 & 2.291 & $\begin{array}{l}2.759 \\
5.6 \%\end{array}$ \\
\hline Center & 83 & 3.779 & $\begin{array}{r}3.862 \\
16.8 \%\end{array}$ & 22.576 & 5.360 & $\begin{array}{l}27.936 \\
41.8 \%\end{array}$ & 8.209 & 3.334 & $\begin{array}{l}11.543 \\
23.5 \%\end{array}$ \\
\hline Lisbon & -- & 9.594 & $\begin{array}{r}9.594 \\
41.8 \%\end{array}$ & -- & 24.394 & $\begin{array}{c}24.394 \\
36 . .5 \%\end{array}$ & - & 23.537 & $\begin{array}{l}23.537 \\
47.8 \%\end{array}$ \\
\hline Alentejo & -2 & 1.893 & $\begin{array}{l}1.891 \\
8.2 \%\end{array}$ & -23 & 3.245 & $\begin{array}{l}3.222 \\
4.8 \%\end{array}$ & -37 & 6.675 & $\begin{array}{r}6.638 \\
13.5 \%\end{array}$ \\
\hline Algarve & 762 & 557 & $\begin{array}{l}1.319 \\
5.7 \%\end{array}$ & 2.644 & 5.064 & $\begin{array}{r}7.708 \\
11.6 \%\end{array}$ & 1.937 & 2.807 & $\begin{array}{l}4.744 \\
9.6 \%\end{array}$ \\
\hline Total & $\begin{array}{r}5.246 \\
22.8 \%\end{array}$ & $\begin{array}{l}17.726 \\
77.2 \%\end{array}$ & $\begin{array}{r}22.972 \\
100.0 \%\end{array}$ & $\begin{array}{l}19.905 \\
29.8 \%\end{array}$ & $\begin{array}{r}46.858 \\
70.20 \%\end{array}$ & $\begin{array}{r}66.763 \\
100.0 \%\end{array}$ & $\begin{array}{l}10.577 \\
21.5 \%\end{array}$ & $\begin{array}{l}38.644 \\
78.5 \%\end{array}$ & $\begin{array}{c}49.221 \\
100.0 \%\end{array}$ \\
\hline
\end{tabular}

Unit: Million of 1999 euros or new jobs.

Table 5: Effects of the investment in SCUTS

\begin{tabular}{|c|c|c|c|c|c|c|c|c|}
\hline Regions & $\begin{array}{c}\text { SCUT } \\
\text { Beira } \\
\text { Interior }\end{array}$ & $\begin{array}{c}\text { SCUT Beiras } \\
\text { Litoral e Alta }\end{array}$ & $\begin{array}{c}\text { SCUT } \\
\text { Grande } \\
\text { Porto }\end{array}$ & $\begin{array}{c}\text { SCUT } \\
\text { Litoral } \\
\text { Norte }\end{array}$ & $\begin{array}{c}\text { SCUT } \\
\text { Costa de } \\
\text { Prata }\end{array}$ & $\begin{array}{c}\text { SCUT } \\
\text { Algarve }\end{array}$ & $\begin{array}{c}\text { SCUT } \\
\text { Interior } \\
\text { Norte }\end{array}$ & $\begin{array}{c}\text { Total effects } \\
\text { by region }\end{array}$ \\
\hline \multicolumn{9}{|c|}{ Effects on private investment } \\
\hline North & 635 & 671 & 1,662 & 966 & 502 & 230 & 1640 & 6,306 \\
\hline Center & 92 & 33 & 1,199 & 697 & 221 & 544 & 1076 & 3,862 \\
\hline Lisbon & 1,880 & 1986 & 1,497 & 869 & 880 & 679 & 1802 & 9,594 \\
\hline Alentejo & 357 & 395 & 298 & 173 & 175 & 135 & 358 & 1,891 \\
\hline Algarve & 117 & 124 & 94 & 54 & 55 & 762 & 113 & 1,319 \\
\hline Total effects by Scut & $\begin{array}{c}3,081 \\
13.4 \% \\
\end{array}$ & $\begin{array}{r}3,209 \\
14.0 \% \\
\end{array}$ & $\begin{array}{r}4,750 \\
20.7 \% \\
\end{array}$ & $\begin{array}{r}2,759 \\
12.0 \% \\
\end{array}$ & $\begin{array}{l}1,833 \\
8.0 \% \\
\end{array}$ & $\begin{array}{c}2,350 \\
10.2 \% \\
\end{array}$ & $\begin{array}{r}4,989 \\
21.7 \% \\
\end{array}$ & $\begin{array}{r}22,972 \\
100.0 \% \\
\end{array}$ \\
\hline \multicolumn{9}{|c|}{ Effects employment } \\
\hline North & 2,938 & 3,102 & $-1,998$ & $-1,161$ & 610 & 1,062 & $-1,050$ & $\mathbf{3 , 5 0 3}$ \\
\hline Center & 8,446 & 9,193 & 1,700 & 988 & 3,153 & 772 & 3,684 & 27,936 \\
\hline Lisbon & 4,780 & 5,049 & 3,805 & 2,211 & 2,238 & 1,728 & 4,583 & 24,394 \\
\hline Alentejo & 592 & 677 & 510 & 296 & 301 & 232 & 614 & 3,222 \\
\hline Algarve & 1,068 & 1,128 & 850 & 494 & 500 & 2,644 & 1,024 & 7,708 \\
\hline Total effects by Scut & $\begin{array}{l}17,824 \\
26.7 \% \\
\end{array}$ & $\begin{array}{l}19,149 \\
28.7 \% \\
\end{array}$ & $\begin{array}{l}4,867 \\
7.3 \% \\
\end{array}$ & $\begin{array}{l}2,828 \\
4.2 \% \\
\end{array}$ & $\begin{array}{r}6,802 \\
10.2 \% \\
\end{array}$ & $\begin{array}{l}6438 \\
9.6 \% \\
\end{array}$ & $\begin{array}{r}8855 \\
13.3 \% \\
\end{array}$ & $\begin{array}{r}66,763 \\
100.0 \% \\
\end{array}$ \\
\hline \multicolumn{9}{|c|}{ Effects on output } \\
\hline North & 763 & 806 & 179 & 104 & 282 & 276 & 349 & 2,759 \\
\hline Center & 3,091 & 3,344 & 1,057 & 615 & 1,224 & 481 & 1,731 & 11,543 \\
\hline Lisbon & 4,613 & 4,871 & 3,670 & 2,134 & 2,160 & 1,667 & 4,422 & $\mathbf{2 3 , 5 3 7}$ \\
\hline Alentejo & 1,230 & 1,392 & 1,049 & 609 & 617 & 476 & 1,265 & 6,638 \\
\hline Algarve & 592 & 625 & 471 & 273 & 277 & 1,938 & 568 & 4,744 \\
\hline Total effects by Scut & $\begin{array}{l}10,289 \\
20.9 \% \\
\end{array}$ & $\begin{array}{l}11,038 \\
22.4 \%\end{array}$ & $\begin{array}{r}6,426 \\
13.1 \%\end{array}$ & $\begin{array}{l}3,735 \\
7.6 \%\end{array}$ & $\begin{array}{l}4,560 \\
9.3 \%\end{array}$ & $\begin{array}{l}4,838 \\
9.8 \%\end{array}$ & $\begin{array}{c}8,335 \\
16.9 \%\end{array}$ & $\begin{array}{c}49,221 \\
100.0 \%\end{array}$ \\
\hline
\end{tabular}

Unit: Million of 1999 euros or new jobs. 
Table 6: On the net economic effects of the investment in SCUTS

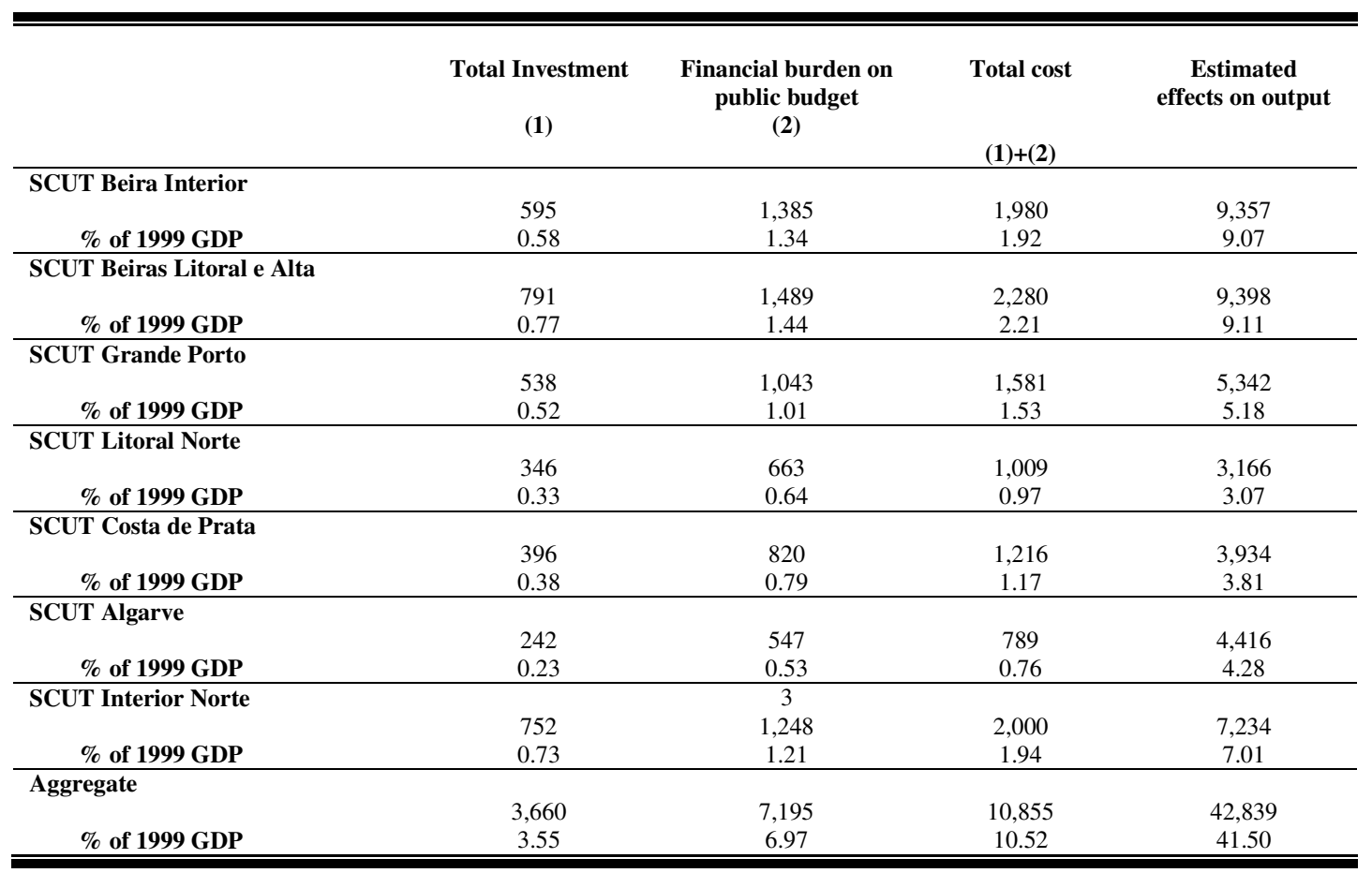

Unit: million 1999 euros; all figures are present discount values using a discount rate of 3\%.

Table 7: On the net budgetary effects of investment by SCUT

\begin{tabular}{|c|c|c|c|}
\hline & $\begin{array}{l}\text { Financial burden } \\
\text { on public budget }\end{array}$ & $\begin{array}{c}\text { Estimated } \\
\text { fiscal revenues }\end{array}$ & $\begin{array}{c}\text { Equilibrium } \\
\text { tax rate }\end{array}$ \\
\hline \multicolumn{4}{|l|}{ SCUT Beira Interior } \\
\hline & 1,385 & 1,965 & $14.8 \%$ \\
\hline$\%$ of 1999 GDP & 1.34 & 1.90 & \\
\hline \multicolumn{4}{|c|}{ SCUT Beiras Litoral e Alta } \\
\hline & 1,489 & 1,974 & $15.8 \%$ \\
\hline$\%$ of 1999 GDP & 1.44 & 1.91 & \\
\hline \multicolumn{4}{|l|}{ SCUT Grande Porto } \\
\hline & 1,043 & 1,122 & $19.5 \%$ \\
\hline$\%$ of 1999 GDP & 1.01 & 1.09 & \\
\hline \multicolumn{4}{|l|}{ SCUT Litoral Norte } \\
\hline & 663 & 665 & $20.9 \%$ \\
\hline$\%$ of 1999 GDP & 0.64 & 0.64 & \\
\hline \multicolumn{4}{|l|}{ SCUT Costa de Prata } \\
\hline & 820 & 826 & $20.8 \%$ \\
\hline$\%$ of 1999 GDP & 0.79 & 0.80 & \\
\hline \multicolumn{4}{|l|}{ SCUT Algarve } \\
\hline & 547 & 927 & $12.4 \%$ \\
\hline$\%$ of 1999 GDP & 0.53 & 0.90 & \\
\hline \multicolumn{4}{|l|}{ SCUT Interior Norte } \\
\hline & 1,248 & 1,519 & $17.3 \%$ \\
\hline$\%$ of 1999 GDP & 1.21 & 1.47 & \\
\hline \multicolumn{4}{|l|}{ Aggregate } \\
\hline & 7,195 & 8,996 & $16.8 \%$ \\
\hline$\%$ of 1999 GDP & 6.97 & 8.72 & \\
\hline
\end{tabular}

Unit: million 1999 euros; all figures are present discount values using a discount rate of 3\%. 